\title{
Redox gradients at the low oxygen boundary of lakes
}

\author{
Mathias K. Kirf • Hans Røy • Moritz Holtappels • Jan P. Fischer • \\ Carsten J. Schubert • Bernhard Wehrli
}

Received: 19 July 2013/ Accepted: 29 July 2014/Published online: 12 September 2014

(C) Springer Basel 2014

\begin{abstract}
The distribution of oxygen $\left(\mathrm{O}_{2}\right)$ at the oxic/ anoxic interface in the water column of two Swiss lakes was measured with sub-micromolar sensitivity, high precision, and high spatial resolution. The $\mathrm{O}_{2}$ distribution was found to be highly variable and it is shown that $\mathrm{N}$-cycling and the redox gradients of $\mathrm{Mn}, \mathrm{Fe}$ and $\mathrm{CH}_{4}$ are controlled by $\mathrm{O}_{2}$ distributions down to the nanomolar concentration range. The profiles reveal that apparent gaps between the oxic zone and the sites of $\mathrm{CH}_{4}$ and $\mathrm{Mn}$ oxidation are bridged by zones with $0.01-1 \mu \mathrm{mol} \mathrm{L} \mathrm{L}^{-1} \mathrm{O}_{2}$ concentrations and thus $\mathrm{CH}_{4}$ and $\mathrm{Mn}$ oxidation clearly occur at oxic
\end{abstract}

Electronic supplementary material The online version of this article (doi:10.1007/s00027 0140365 4) contains supplementary material, which is available to authorized users.

M. K. Kirf $(\bowtie) \cdot$ C. J. Schubert · B. Wehrli

Department of Surface Waters, Research and Management, Eawag, Swiss Federal Institute of Aquatic Science and Technology, Seestrasse 79, 6047 Kastanienbaum, Switzerland e mail: mathias@kirf.de

M. K. Kirf · B. Wehrli

Institute of Biogeochemistry and Pollutant Dynamics, ETH

Zurich, Universitätsstrasse 16, 8092 Zurich, Switzerland

\section{H. Røy}

Center for Geomicrobiology, Department of Bioscience, Aarhus University, Ny Munkegade 116, 8000 Aarhus C, Denmark

e mail: hans.roy@biology.au.dk

\section{Holtappels}

Department of Biogeochemistry, Max Planck Institute for Marine Microbiology, Celsiusstrasse 1, 28359 Bremen, Germany

e mail: mholtapp@mpi bremen.de

\section{J. P. Fischer}

Institute of Analytical Chemistry and Food Chemistry, Graz University of Technology, Stremayrgasse 9, 8010 Graz, Austria e mail: fischer@tugraz.at conditions. Directly below the steep oxycline of Lake Rot a broad low $\mathrm{O}_{2}$ zone in the depth range of 6-7.5 $\mathrm{m}$ was now detectable. The $\mathrm{O}_{2}$ increase during daylight in this zone was comparable to the $\mathrm{O}_{2}$ flux along the oxycline. Here photosynthesis could be responsible for a substantial part of the chemotrophic oxidation processes. An even broader zone $(0.8-3.8 \mathrm{~m})$ with sub-micromolar $\mathrm{O}_{2}$ and evidence for methanotrophic and lithotrophic activities found at $160 \mathrm{~m}$ depth in the deep, dark hypolimnion of Lake Zug was maintained by transport, reaction- and mixing processes. The submicromolar zones could not have been resolved with traditional CTD-profiles. Their existence expands the oxic zone downwards and implies that substantial parts of "suboxic zones" characterized by the absence of both $\mathrm{O}_{2}$ and $\mathrm{H}_{2} \mathrm{~S}$ may actually belong to the realm of oxic processes if more sensitive measurement techniques are used for their characterization.

Keywords Oxic/anoxic interface $\cdot$ Nanomolar oxygen Optode $\cdot$ Microsensor $\cdot$ Redox boundary .

Deep oxygenic photosynthesis - Hypoxia - Suboxic ·

Methane $\cdot$ Nitrogen transformation

\section{Introduction}

Most aquatic animals cannot sustain oxic respiration below $\sim 60 \mu \mathrm{mol} \mathrm{O}_{2} \mathrm{~L}^{-1}$ (Gray et al. 2002; Keeling et al. 2010) and this limit can be used to define hypoxia in aquatic environments. Only below $\sim 5 \mu \mathrm{mol} \mathrm{O}_{2} \mathrm{~L}^{-1}$, however, does $\mathrm{NO}_{3}{ }^{-}$become a preferred terminal electron acceptor (TEA) for facultative aerobic microorganisms, and aerobic microbial respiration continues without kinetic limitation down to the nanomolar range (Stolper et al. 2010). Thus, there is ample space for complex redox cycling at or below 
the detection limit of traditional analytical techniques at around $1 \mu \mathrm{mol} \mathrm{L}{ }^{-1}$ (Berner 1981; Canfield and Thamdrup 2009). Indeed, marine in situ studies with Switchable Trace $\mathrm{O}_{2}$ (STOX) sensors (Revsbech et al. 2009; Kalvelage et al. 2011; Thamdrup et al. 2012) indicated that a detection limit of $1 \mu \mathrm{mol} \mathrm{O} \mathrm{O}_{2} \mathrm{~L}^{-1}$ is by at least one order of magnitude too high to adequately detect and classify $\mathrm{O}_{2}$ dependent redox-interactions in natural systems.

Redox cycling at very low $\mathrm{O}_{2}$ concentrations is relevant for oxic/anoxic interfaces in sediments and water columns. Both, the production and the removal of major greenhousegases $\left(\mathrm{CH}_{4}, \mathrm{~N}_{2} \mathrm{O}\right.$; Lashof and Ahuja 1990) as well as the loss of reactive nitrogen from biological systems are strongly related to such $\mathrm{O}_{2}$-induced changes in the TEA (Seitzinger et al. 1984; Mulder et al. 1995; Lam and Kuypers 2011). A multitude of transformation pathways can co-occur at oxic/ anoxic interfaces interconnecting the cycles of different elements (Lam and Kuypers 2011; Kalvelage et al. 2011).

In this study, the oxic/anoxic transition in two Swiss lakes, holomictic Lake Rot and meromictic Lake Zug is explored in detail using a custom made profiling in-situ analyzer (PIA) (Kirf et al. 2013). The PIA enables continuous high-resolution profiling across steep oxic/anoxic transitions with sensitivity in the nanomolar range and online data-monitoring to allow targeted sampling. Snapshots of chemical gradients are presented together with submicromolar $\mathrm{O}_{2}$ profiles in order to investigate how submicromolar $\mathrm{O}_{2}$ concentrations interact with the cycling of $\mathrm{N}, \mathrm{Mn}, \mathrm{Fe}, \mathrm{S}$ and $\mathrm{CH}_{4}$ and whether the applied sensors can resolve the relevant range of $\mathrm{O}_{2}$ concentrations. The high-resolution $\mathrm{O}_{2}$ profiles revealed previously unnoticed, extensive and highly variably zones of submicromolar $\mathrm{O}_{2}$ concentrations, where important redox transformations, e.g. $\mathrm{CH}_{4}$-oxidation or nitrification, can occur.

\section{Materials and methods}

\section{Study sites}

Studies were conducted in two Swiss lakes chosen for their different stratification. Lake Rot is seasonally stratified with a steep thermocline that co-occurs with the oxic/ anoxic interface. In Lake Zug, the oxic/anoxic transition occurs deep in the permanently, but weakly stratified hypolimnion.

Lake Rot $\left(47.07^{\circ} \mathrm{N}, 8.32^{\circ} \mathrm{E}\right)$ is a holomictic eutrophic prealpine lake close to the city of Lucerne, Switzerland with a surface area of $0.46 \mathrm{~km}^{2}$, a volume of $0.0039 \mathrm{~km}^{3}$ and a mean hydraulic residence time of 0.4 year (Kohler et al. 1984). Measurements were performed in the deepest part of the lake $(\sim 16 \mathrm{~m}$, online resource 1$)$. The lake is shielded from winds and a stable stratification (gradient of
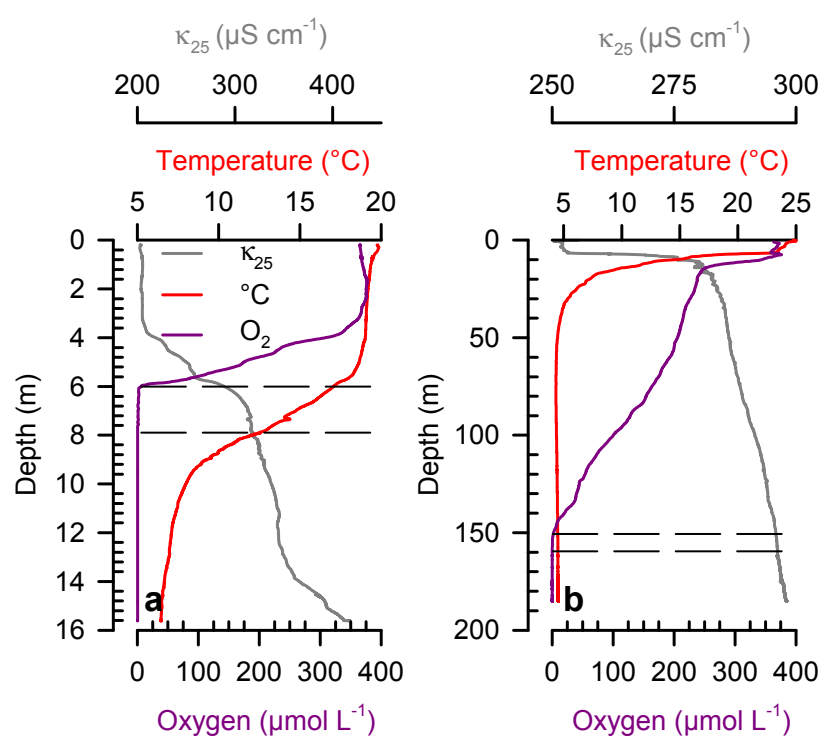

Fig. 1 Synoptical profiles of the physical gradients and the $\mathrm{O}_{2}$ distribution in the water column of Lake Rot (a) and Lake Zug (b). Dashed lines indicate zones with low to submicromolar $\mathrm{O}_{2}$ concentrations

temperature $(\Delta T) \sim 2{ }^{\circ} \mathrm{C} \mathrm{m}^{-1}$, gradient of specific conductivity (corrected to $25{ }^{\circ} \mathrm{C}, \Delta k_{25}$ ) $\sim 10 \mu \mathrm{S} \mathrm{cm}^{-1} \mathrm{~m}^{-1}$ ) establishes between May and November with a strong chemocline at $8-11 \mathrm{~m}$ and an euxinic hypolimnion (Schubert et al. 2010) (Fig. 1a).

Meromictic Lake $\mathrm{Zug}\left(47.10^{\circ} \mathrm{N}, 8.48^{\circ} \mathrm{E}\right)$ in central Switzerland has a maximum depth of $198 \mathrm{~m}$, a surface area of $38.3 \mathrm{~km}^{2}$, a volume of $3.2 \mathrm{~km}^{3}$ and a mean hydraulic residence time of $\sim 14$ years (Maerki et al. 2009). Measurements have been performed near the deepest site $(198 \mathrm{~m})$ in the south basin (online resource 1) which is shielded from westerly winds by high mountains and not influenced by the main inflow. Lake Zug remains permanently anoxic below $160 \mathrm{~m}$ despite a weakly stratified hypolimnion with a weak, reversed temperature gradient below $80 \mathrm{~m}\left(\Delta T<0.002{ }^{\circ} \mathrm{C} \mathrm{m}^{-1}, \Delta k_{25}<0.1 \mu \mathrm{S} \mathrm{cm}^{-1} \mathrm{~m}^{-1}\right)$ (Fig. 1b) caused by the geothermal heat flux.

Profiling in-situ analyzer (PIA)

All in situ measurements and the online-controlled water sampling was performed with the PIA (Kirf et al. 2013). It is equipped with two independent $\mathrm{O}_{2}$ sensor systems optimized for low $\mathrm{O}_{2}$ concentrations based on microoptodes (TOS7-dye, $140 \mu \mathrm{m}$ tip-diameter, white optical isolation, PreSens) and clark-type amperometric $\mathrm{O}_{2}$ microsensors (Ox-25, Unisense). In this study, the optical sensors with a response time of $7 \mathrm{~s}$ were used to resolve submicromolar $\mathrm{O}_{2}$ concentrations.

Instruments were mounted at the outside of an open cubic aluminium-frame of $50 \times 50 \times 60 \mathrm{~cm}$ which held 
on its top the central processing unit and its power supply and left room in the centre for a carousel syringe sampler (KC Denmark) with $12 \times 60 \mathrm{ml}$ plastic syringes (Omnifix, B. Brown). If a higher sampling-volume was preferred over a higher number of samplings per cast, a custom-made actuator allowed simultaneous sampling of multiple syringes at a given depth. Two-way communication along a galvanically isolated load-carrying data-cable allowed online evaluation of depth-profiles on shipboard via a laptop computer and enabled targeted sampling. Using an electrical winch, profiles were recorded with dive speeds between 0.2 and $0.9 \mathrm{~m} \mathrm{~min}^{-1}$ in Lake Rot and between 1.0 and $3.6 \mathrm{~m} \mathrm{~min}^{-1}$ in Lake Zug (see online resource 2). Between profiles, the boat-position was changed by several meters to an undisturbed spot.

\section{$\mathrm{O}_{2}$ measurements}

Pressure, conductivity and temperature were recorded by a CTD (XR-420, RBR) with a sampling rate of $2 \mathrm{~Hz}$. The microoptode was calibrated to $\mathrm{O}_{2}$ partial pressure based on the Stern Volmer equation (Lippitsch et al. 1988) by a two point calibration in the laboratory with nanopure water $\left(4{ }^{\circ} \mathrm{C}\right)$ equilibrated with certified gas mixtures $(0.00$ and $1.59 \% \mathrm{O}_{2}$; PanGas) for the anoxic and the oxic calibration point, respectively. The obtained curve was recalibrated in situ with a one point calibration at anoxic in situ conditions. The microoptodes were sampled at $1 \mathrm{~Hz}$ and the in situ detection limits (calculated as two times the standard deviation in the anoxic water column) were $12.4 \pm 0.5 \mathrm{nmol} \mathrm{O}_{2}$ $\mathrm{L}^{-1}(n=9)$ for the microoptode used on 6 August 2010 in Lake Zug and $8.4 \pm 0.6 \mathrm{nmol} \mathrm{O}_{2} \mathrm{~L}^{-1}(n=13)$ and $8.3 \pm 0.8 \mathrm{nmol} \mathrm{O}_{2} \mathrm{~L}^{-1}(n=9)$ for the microoptode used on 25 August 2010 in Lake Zug and on 14 September 2010 in Lake Rot, respectively. $\mathrm{O}_{2}$ concentrations above $35 \mu \mathrm{mol}$ $\mathrm{L}^{-1}$ were measured with amperometric microsensors, which were calibrated by a linear two-point in situ calibration using Winkler-derived (Winkler 1888) epilimnetic $\mathrm{O}_{2}$-concentrations and the anoxic water column (Kirf et al. 2013).

The $\mathrm{O}_{2}$ partial pressure in water was related to $\mathrm{O}_{2}$ concentrations $C_{\mathrm{O}_{2}}^{*}$ at standard pressure $\mathrm{p}^{*}$ of $101,325 \mathrm{~Pa}$ (real gas). $C_{\mathrm{O}_{2}}^{*}$ was computed as a function of salinity and temperature according to Garcia and Gordon (1992) using the solubility coefficients derived from the data of Benson and Krause (1984) and converted to values of $\mu \mathrm{mol} \mathrm{L}^{-1}$ using a density of $1 \mathrm{~kg} \mathrm{~L}^{-1}$. Molar concentrations were used because they are independent of temperature and pressure, and facilitate mass balance calculations and modelling.

Chemical analysis

Water samples for dissolved nutrient analysis were filtered directly from the syringes through $0.45 \mu \mathrm{m}$ cellulose-acetate disc filters (FP30/0.45CA, Whatman) into polyethylenebottles, immediately placed at $4{ }^{\circ} \mathrm{C}$ in darkness and analyzed within $32 \mathrm{~h}$. $\mathrm{NO}_{3}^{-}, \mathrm{NO}_{2}{ }^{-}$and $\mathrm{NH}_{4}{ }^{+}$were colorimetrically analyzed following standard methods (DEV 2004). $\mathrm{NO}_{3}{ }^{-}$ was measured after reduction to $\mathrm{NO}_{2}^{-}$on a cadmium column with a flow injection analyzer (detection limit: $700 \mathrm{nmol} \mathrm{L}^{-1}$, Skalar SAN+ system, Skalar Analytical) using sulfanilamide and $N$-(1-naphytyl)-ethylenediammonium chloride. $\mathrm{NO}_{2}{ }^{-}$(detection limit: $35 \mathrm{nmol} \mathrm{L}{ }^{-1}$ ) and $\mathrm{NH}_{4}^{+}$(detection limit: $500 \mathrm{nmol} \mathrm{L}{ }^{-1}$ ) were determined by photometric analysis (Hitachi U-2000 spectrophotometer, Hitachi High Technologies) with a $10 \mathrm{~cm}$ cuvette at 543 and $690 \mathrm{~nm}$, respectively.

To analyze dissolved and particulate $\mathrm{Mn}$ and $\mathrm{Fe}, 8 \mathrm{ml}$ of filtered (FP30/0.45CA, Whatman, $0.45 \mu \mathrm{m}$ pore size) and $8 \mathrm{ml}$ of unfiltered water-sample were collected in Falcon tubes (BD Falcon, BD Biosciences) and acidified with $150 \mu \mathrm{L}$ of concentrated $\mathrm{HNO}_{3}$ (Suprapur $65 \%$, Merck). After separate analysis by inductively coupled plasma optical emission spectroscopy (Spectro Arcos ICP-OES, Spectro Analytical Instruments, detection limits: Mn: $2 \mathrm{nmol}(257.611 \mathrm{~nm})$, Fe: $4 \mathrm{nmol}(238.204 \mathrm{~nm})$ ), the particulate $\mathrm{Mn}$ and Fe concentrations were calculated by subtracting the dissolved metalconcentrations obtained from the filtered sample from the total metal concentrations obtained from the unfiltered sample.

For analysis of sulphide as $\Sigma \mathrm{H}_{2} \mathrm{~S}\left(\mathrm{H}_{2} \mathrm{~S}, \mathrm{HS}^{-}, \mathrm{S}^{2-}\right)$ after precipitation as $\mathrm{ZnS}$ according to Cline (1969), $2 \mathrm{ml}$ of water-sample was conserved in $1 \mathrm{~mL}$ of $4 \% \mathrm{Zn}$ acetate in $2 \%$ acetic acid and stored dark at $4{ }^{\circ} \mathrm{C}$ until photometric measurement within $32 \mathrm{~h}$ with a $1 \mathrm{~cm}$ cuvette at $670 \mathrm{~nm}$ (detection limit: $2 \mu \mathrm{mol} \mathrm{L}{ }^{-1}$, Hitachi U-2000 spectrophotometer, Hitachi High Technologies).

Samples for combined measurement of $\mathrm{CH}_{4}$ and $\mathrm{N}_{2} \mathrm{O}$ were collected in $\mathrm{N}_{2}$-purged and pressurized $60 \mathrm{ml}$ glassbottles preloaded with $\sim 0.1 \mathrm{~g}$ copper(I) chloride and closed with new butyl-rubber septa. After on-site pressure equilibration, the sample-volume equivalent of $\mathrm{N}_{2}$ was removed and substituted by up to $35 \mathrm{ml}$ of unfiltered water sample. Dissolved $\mathrm{CH}_{4}$ and $\mathrm{N}_{2} \mathrm{O}$ were measured on a gas chromatograph $(6890 \mathrm{~N}$, Agilent Technologies) with a flame ionization detector and an electron capture detector, respectively. Dissolved gas concentrations were calculated using solubility data from Wiesenburg and Guinasso (1979) for $\mathrm{CH}_{4}$ and from Weiss and Price (1980) for $\mathrm{N}_{2} \mathrm{O}$.

\section{Lake Rot campaign}

On 14 September 2010, samples for reactive nitrogen $\left(\mathrm{NO}_{3}^{-}, \mathrm{NO}_{2}^{-}, \mathrm{NH}_{4}^{+}\right)$and trace gases $\left(\mathrm{CH}_{4}, \mathrm{~N}_{2} \mathrm{O}\right)$ were retrieved during two consecutive sets of casts that provided up to 12 individual samples. For each set, one low-resolution cast across the whole water column and two highresolution sampling casts covering the low-oxic to anoxic 
transition were performed. Concentrations of dissolved and particulate $\mathrm{Mn}, \mathrm{Fe}$ and for $\mathrm{\Sigma H}_{2} \mathrm{~S}$ were analyzed for all casts. Data are missing for the third syringe in Fig. 4a due to a failed release.

\section{Lake Zug campaign}

On 21 July 2010, a synoptic concentration profile spanning the 130-180 $\mathrm{m}$ depth-interval was sampled at a low resolution of 1-2 $\mathrm{m}$ and concentrations of nutrients, $\mathrm{Mn}, \mathrm{Fe}$, $\mathrm{N}_{2} \mathrm{O}$ and $\mathrm{CH}_{4}$ were analyzed. High-resolution samplingcasts across the oxic/anoxic interface providing up to 12 individual water samples were separately performed for nutrient analysis on 25 August 2010 and gas-analysis on 6 August 2010, while $\mathrm{Mn}, \mathrm{Fe}$ and $\Sigma \mathrm{H}_{2} \mathrm{~S}$-concentrations were analyzed for each cast.

\section{Results}

Lake Rot: physical structure and $\mathrm{O}_{2}$ profiles

The density structure of Lake Rot is governed by strong temperature gradients (Fig. 1a) separating a well-mixed epilimnion with a depth of $4.6 \mathrm{~m}$ (Fig. 2b) from a strongly stratified water column below with an average density gradient of $0.4 \mathrm{~kg} \mathrm{~m}^{-4}$ between 5.5 and $8.5 \mathrm{~m}$ (Fig. 2b). Depth-deviations between identical density-values were typically less than $40 \mathrm{~cm}$ among individual dives.

Epilimnetic $\mathrm{O}_{2}$ concentrations increased during daytime with a maximum $\mathrm{O}_{2}$-increase occurring at $2 \mathrm{~m}$ depth (Fig. 2a). Between 4.8 and $\sim 6 \mathrm{~m}$, all profiles show a welldeveloped and highly reproducible oxycline. The $\mathrm{O}_{2}$ concentration decreased nearly linearly from 350 to $5 \mu \mathrm{mol} \mathrm{L} \mathrm{L}^{-1}$ with an average gradient of $\sim 210 \mu \mathrm{mol} \mathrm{L}^{-1} \mathrm{~m}^{-1}$ (Fig. 2a). At the lower end of the steep oxycline, however, we observed a $1.5 \mathrm{~m}$ thick layer with highly variable low $\mathrm{O}_{2}$ conditions (Fig. 2c). $\mathrm{O}_{2}$ peaks of up to $6 \mu \mathrm{mol} \mathrm{O}_{2} \mathrm{~L}^{-1}$ were separated by water with only nanomolar $\mathrm{O}_{2}$ concentrations. Although vertical $\mathrm{O}_{2}$-distribution thus varied strongly and sampling locations were changed between individual casts, most peaks appeared at similar relative depths below the oxycline (Fig. 2c). Their alignment further improved when plotted against density (Fig. 2d). As observed in the epilimnion, $\mathrm{O}_{2-}$ concentrations in this low $\mathrm{O}_{2}$ zone increased with the duration of daylight. Since $\mathrm{O}_{2}$ dropped below the detection limit several times within the low $\mathrm{O}_{2}$ zone (Fig. 2c), we operationally defined the oxic/anoxic interface as the deepest location with detected $\mathrm{O}_{2}$ concentrations above $100 \mathrm{nmol} \mathrm{L}{ }^{-1}$. These positions are located about $1-1.5 \mathrm{~m}$ below the lower end of the continuous oxycline in Fig. 2c and are marked in Figs. 1a and 4 with dashed lines. Further details of the casts are summarized in online resource 2.
Lake Rot: gradients of $\mathrm{NO}_{3}{ }^{-}, \mathrm{NO}_{2}{ }^{-}, \mathrm{N}_{2} \mathrm{O}$ and $\mathrm{NH}_{4}{ }^{+}$

Oxidized and reduced $\mathrm{N}$-species co-occurred at the lower end of the steep oxycline at $\sim 6 \mathrm{~m}$ (Fig. 3b, e). Maximum $\mathrm{NO}_{3}{ }^{-}$concentrations of up to $20 \mu \mathrm{mol} \mathrm{L}{ }^{-1}$ were measured closely above at $5.5 \mathrm{~m}$ (Fig. 4b), but $\mathrm{NO}_{3}{ }^{-}$dropped sharply within $40 \mathrm{~cm}$ below the oxycline to background concentrations $<0.7 \mu \mathrm{mol} \mathrm{L}{ }^{-1}$. Epilimnetic $\mathrm{NO}_{3}{ }^{-}$concentrations were low at 5-7 $\mu \mathrm{mol} \mathrm{L} \mathrm{L}^{-1}$ (Fig. 4a).

Directly below the oxycline in the depth range of decreasing $\mathrm{NO}_{3}{ }^{-}$concentrations, narrow $\mathrm{NO}_{2}{ }^{-}$and $\mathrm{N}_{2} \mathrm{O}$ peaks with maxima of 5 and $150 \mathrm{nmol} \mathrm{L}^{-1}$, respectively, were detected (Fig. 3b, e). $\mathrm{NO}_{2}{ }^{-}$vanished together with $\mathrm{NO}_{3}{ }^{-}$at $6.4 \mathrm{~m}$ (Fig. 4b), while $\mathrm{N}_{2} \mathrm{O}$ reached background concentrations at $6.7 \mathrm{~m}$ (Fig. $4 \mathrm{e}$ ).

The gradient of $\mathrm{NH}_{4}{ }^{+}$implies a flux of $\mathrm{NH}_{4}{ }^{+}$from the sediment into the low $\mathrm{O}_{2}$ zone (Fig. 4a). The $\mathrm{NH}_{4}{ }^{+}$gradient was almost linear above $10 \mathrm{~m}$, it crossed the low $\mathrm{O}_{2}$ zone apparently unchanged and extended well into the oxic water column (Fig. 3b). In epilimnetic waters, only background concentrations around $0.6 \mu \mathrm{mol} \mathrm{L}^{-1}$ were measured, but due to the missing sample at $4 \mathrm{~m}$ (Fig. 4a), the progression of the $\mathrm{NH}_{4}{ }^{+}$gradient as well as the $\mathrm{NO}_{3}{ }^{-}$concentrations are underdetermined between 5.5 and $3 \mathrm{~m}$. However, the linear extrapolation of the $\mathrm{NH}_{4}^{+}$gradient of the high-resolution profile (Fig. 3b) reaches background concentrations at $\sim 5 \mathrm{~m}$ and at $\mathrm{O}_{2}$ concentrations $>100 \mu \mathrm{mol} \mathrm{L}{ }^{-1}$, and the $\mathrm{NO}_{3}{ }^{-}$profiles indicate a $\mathrm{NO}_{3}{ }^{-}$peak at or above $5.5 \mathrm{~m}$ (Figs. 3b, 4a).

Lake Rot: redox gradients of dissolved $\mathrm{Mn}, \mathrm{Fe}, \mathrm{CH}_{4}$ and $\Sigma \mathrm{H}_{2} \mathrm{~S}$

The gradients of dissolved $\mathrm{Mn}$ and Fe imply a flux from below towards the low $\mathrm{O}_{2}$ zone (Fig. 4c). Directly at the lower end of the low $\mathrm{O}_{2}$ zone, the $\mathrm{Mn}^{2+}$-gradient ends and a pronounced particulate Mn-peak is observed. Thus, the Mn (Fig. 3c, f) and less so the Fe profiles (Fig. 3f) show a sharp transition between the reduced and oxidized form at the oxic/anoxic interface located up to $1.5 \mathrm{~m}$ below the steep oxycline and show a clear separation from the redoxtransition of the $\mathrm{N}$-species (Fig. 3b, e).

The gradient of $\mathrm{CH}_{4}$ with deep-water concentrations of $800 \mu \mathrm{mol} \mathrm{CH}_{4} \mathrm{~L}^{-1}$ implies a flux of $\mathrm{CH}_{4}$ from the sediment towards the low $\mathrm{O}_{2}$ zone (Fig. $4 \mathrm{~b}$ ). $\mathrm{CH}_{4}$ vanished at the oxic/ anoxic interface and thus about $1.5 \mathrm{~m}$ below the steep oxycline together with $\mathrm{Mn}^{2+}$, indicating oxidation with $\mathrm{O}_{2}$ (Fig. 3e, f). As samples were analyzed in parallel for their $\mathrm{CH}_{4^{-}}$and $\mathrm{N}_{2} \mathrm{O}$ concentrations, the profiles in Figs. $3 \mathrm{e}$ and $4 \mathrm{~b}$ corroborate a clear separation of the zones of $\mathrm{CH}_{4}$-oxidation and $\mathrm{N}$-cycling. $\Sigma \mathrm{H}_{2} \mathrm{~S}$ was detected only below $8.5 \mathrm{~m}$ and thus about $1 \mathrm{~m}$ below the low $\mathrm{O}_{2}$ zone (Figs. 3e, $4 \mathrm{~b}$, online resource 1). 

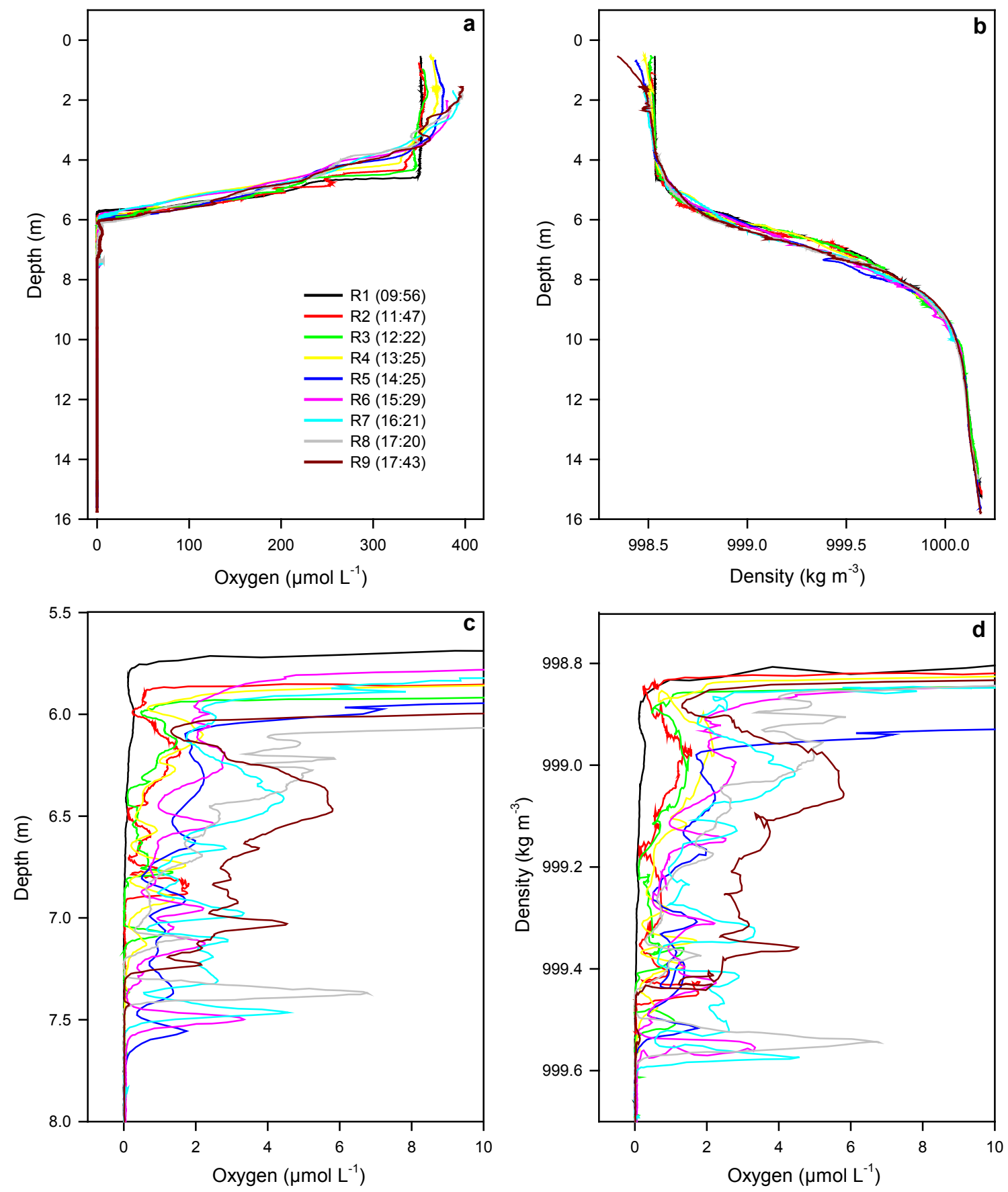

Fig. 2 Lake Rot, 14 September 2010: high resolution $\mathrm{O}_{2}$ and density profiles of the water column $(\mathbf{a}, \mathbf{b}) . \mathrm{O}_{2}$ profiles enlarged around the lower end of the oxycline (c) and density plotted against low $\mathrm{O}_{2}$

values (d). Legend states time of crossing of the oxic/anoxic interface during casts R1 R9

$2.2 \mu \mathrm{mol} \mathrm{L} \mathrm{L}^{-1} \mathrm{~m}^{-1}$ (Fig. 1b). Lake Zug's whole hypolimnion was weakly stratified and the position of the oxic/anoxic interface was not associated to any prominent physical feature. The lower end of the weak $\mathrm{O}_{2}$ gradient in Lake Zug showed a broad submicromolar zone (Fig. 5a, d, g) defined as the water layer in which $\mathrm{O}_{2}$ concentrations range from 1 to 

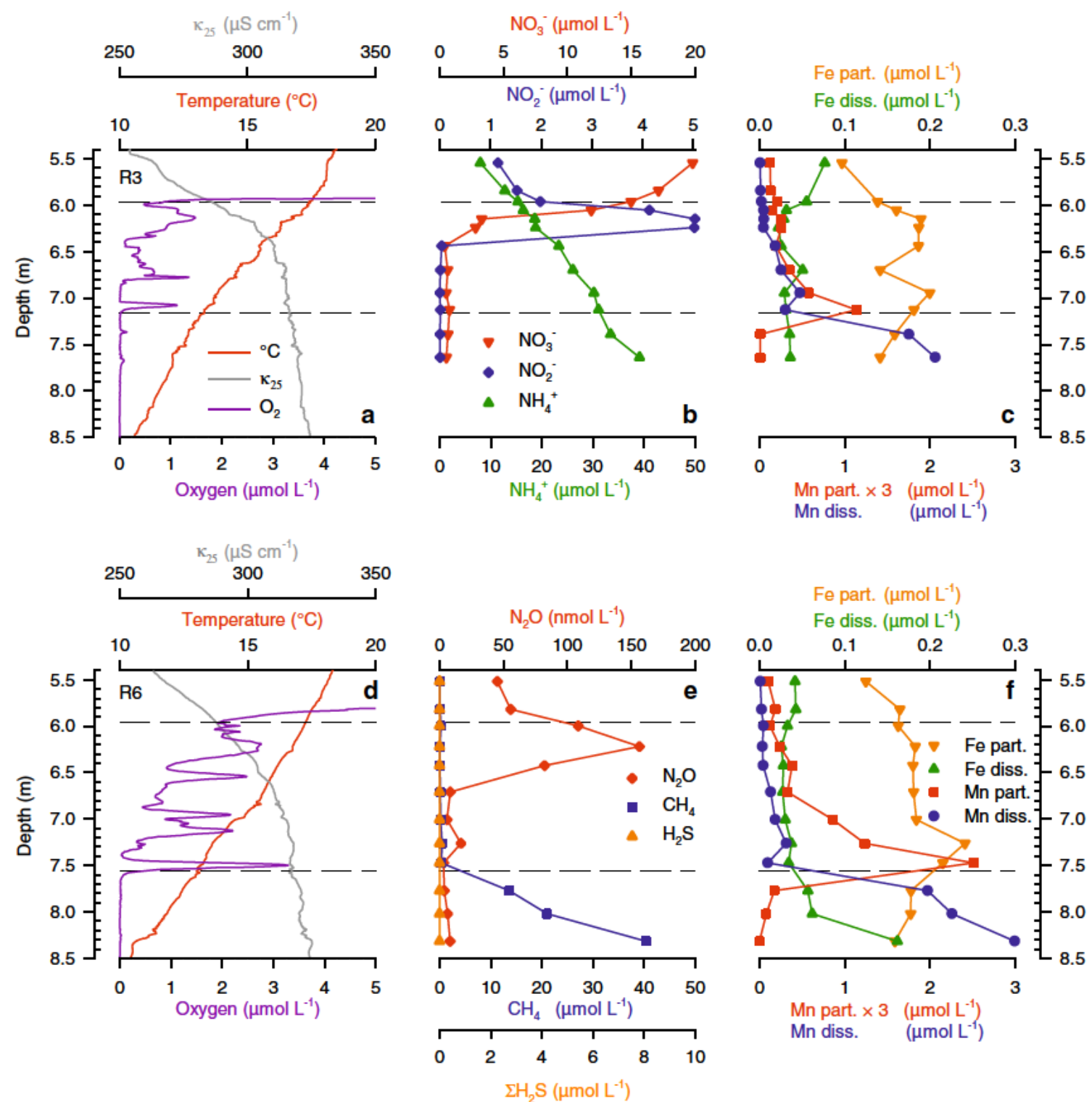

Fig. 3 Lake Rot, 14 September 2010: depth profiles of cast R3 (top) and R6 (bottom) across the oxic/anoxic interface showing the distribution of $\mathrm{O}_{2}\left(\mathbf{a}\right.$, d), $\mathrm{N}$ species (b, e), $\mathrm{H}_{2} \mathrm{~S}$ and $\mathrm{CH}_{4}$ (e) and transition metals (c, $\mathbf{f}$, particular Mn values have been multiplied by 3) together with physical gradients (a, d). Dashed lines indicate the

$0.01 \mu \mathrm{mol} \mathrm{O} \mathrm{L}^{-1}$, where the lowest concentration is set by the detection limit of the microoptode. The depth of the oxic/ anoxic interface was variable between casts, ranging from 149 to $161 \mathrm{~m}$ depth (further details of the casts are summarized in online resource 2). However, the interface was not associated to a specific density layer (data not shown).

The thickness and structure of the submicromolar zone varied in consecutive casts (Fig. $5 \mathrm{a}, \mathrm{d}, \mathrm{g}$ ). In cast $\mathrm{Z1}$ (Fig. 5a), $\mathrm{O}_{2}$ decreased smoothly towards the oxic/anoxic interface at $151 \mathrm{~m}$, but small oxic pockets were detected at 1 and $6 \mathrm{~m}$ below the interface. Cast Z10 (Fig. 5d) revealed a $\sim 3 \mathrm{~m}$ thick layer with nearly constant nanomolar $\mathrm{O}_{2}$-levels upper and lower boundaries of the low $\mathrm{O}_{2}$ zone observed directly below the steep oxycline. Redox horizons of $\mathrm{N}$ species (b, e), $\mathrm{CH}_{4}$ (e) and transition metals (c, f) are closely associated to these boundaries

situated above a prominent oxic pocket close to the oxic/ anoxic interface located at $\sim 156 \mathrm{~m}$. In cast Z11 (Fig. 5g), the position of the oxic/anoxic interface was similar to the previous cast but the thickness of the submicromolar zone was reduced to $1 \mathrm{~m}$. Consecutive $\mathrm{O}_{2}$ profiles obtained 19 days earlier (Fig. 6a, d, online resource 2) show similar variability in the position, thickness and structure of the submicromolar zone. In summary, the thickness of the submicromolar zones were between $1.7 \pm 0.8 \mathrm{~m}(n=9)$ and $2.0 \pm 0.9 \mathrm{~m}(n=13)$ on 6 and 25 August 2010, respectively. Above $1 \mu \mathrm{mol} \mathrm{O} \mathrm{O}_{2} \mathrm{~L}^{-1}$, all casts showed steps and small inversions in the $\mathrm{O}_{2}$ gradients at different depths. 

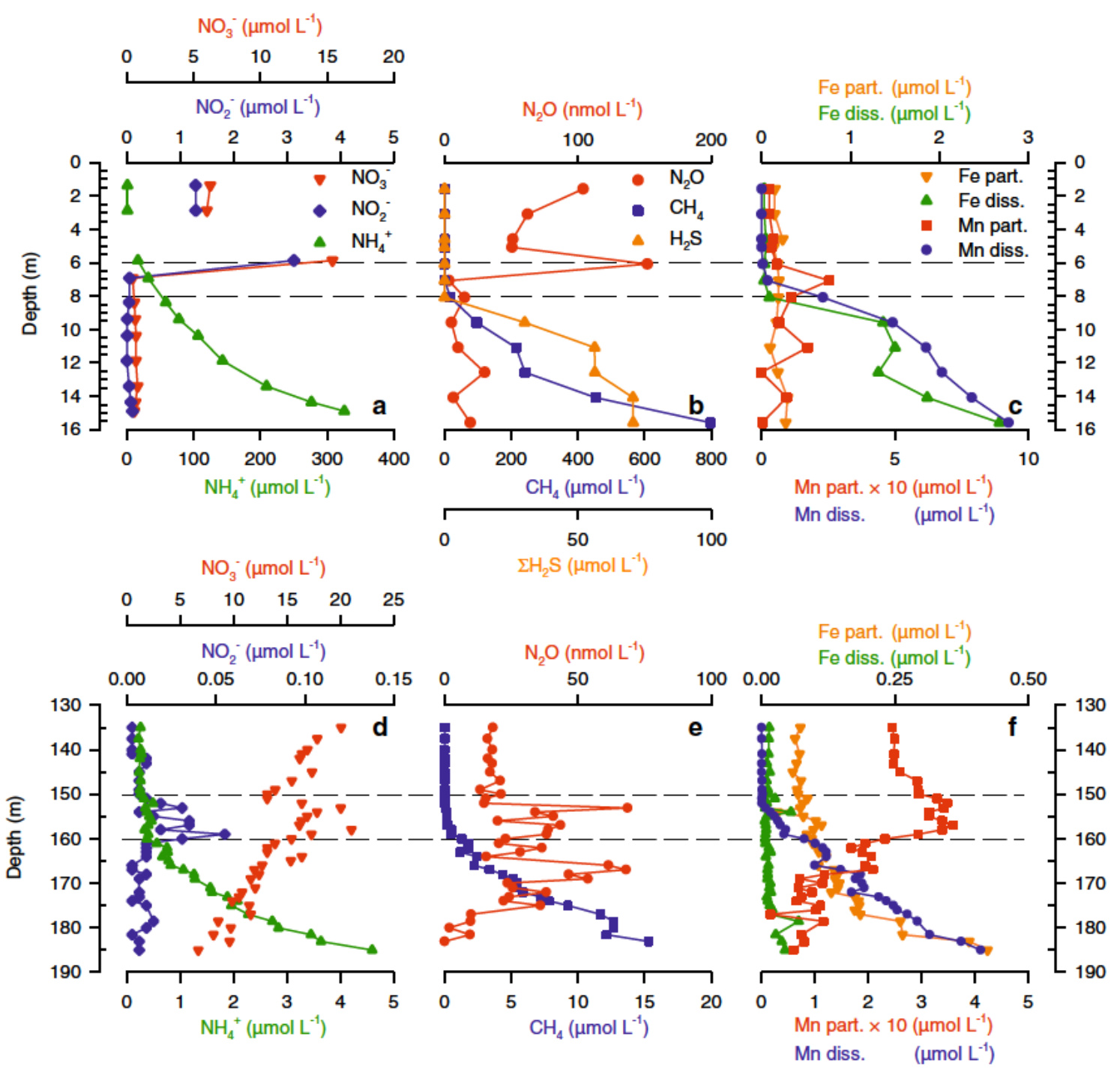

Fig. 4 Synoptical profiles of Lake Rot (top) and Lake Zug (bottom) showing the distribution of $\mathrm{N}$ species (a, b, d, e), $\mathrm{CH}_{4}(\mathbf{b}, \mathbf{e}), \mathrm{H}_{2} \mathrm{~S}$ (b) and transition metals (c, f, particular Mn values have been

Lake Zug: gradients of $\mathrm{NO}_{3}{ }^{-}, \mathrm{NO}_{2}{ }^{-}, \mathrm{N}_{2} \mathrm{O}$ and $\mathrm{NH}_{4}{ }^{+}$

Redox-transformations of $\mathrm{NO}_{3}^{-}, \mathrm{NO}_{2}^{-}$, and $\mathrm{NH}_{4}^{+}$were observed close to the position of the oxic/anoxic interface (Fig. 5b, e, f). But in contrast to Lake Rot, $\mathrm{NO}_{3}{ }^{-}$showed no prominent changes across the submicromolar zones but extended to below $180 \mathrm{~m}$ (Figs. $5 \mathrm{~b}, \mathrm{e}, \mathrm{h}, 4 \mathrm{~d}$ ). However, local $\mathrm{NO}_{3}{ }^{-}$minima and maxima (Fig. $5 \mathrm{e}, \mathrm{h}$ ) are found at the oxic/anoxic transition where they correspond with 2$4 \mathrm{~m}$ broad and concise $\mathrm{NO}_{2}{ }^{-}$peaks reaching their maxima of up to $65 \mathrm{nmol} \mathrm{L}^{-1}$ either below (Fig. 5e) or at the lower end (Fig. 5b, h) of the submicromolar zone. $\mathrm{NH}_{4}{ }^{+}$profiles indicated upward transport of $\mathrm{NH}_{4}{ }^{+}$and the resolved end of the $\mathrm{NH}_{4}^{+}$gradient was almost linear (Fig. 5b, h). However, $\mathrm{NH}_{4}{ }^{+}$concentrations fell below the detection multiplied by 10). Dashed lines indicate zones with low to submicromolar $\mathrm{O}_{2}$ concentrations. Data is missing for the third syringe in panel a due to a failed release

limit at $2-4 \mathrm{~m}$ below the oxic/anoxic interface. $\mathrm{N}_{2} \mathrm{O}$ concentrations increased close to and below the oxic/ anoxic interface (Figs. 6b, e, 4e). But compared to Lake Rot, absolute $\mathrm{N}_{2} \mathrm{O}$-concentrations were lower and no distinct peaks were measured.

Lake Zug: redox gradients of dissolved $\mathrm{Mn}, \mathrm{Fe}, \mathrm{CH}_{4}$ and $\Sigma \mathrm{H}_{2} \mathrm{~S}$

The nearly linear gradients of dissolved $\mathrm{Mn}^{2+}$ terminated close to the oxic/anoxic interface (Fig. 4f). High resolution profiles show that dissolved $\mathrm{Mn}$ is removed already at the lower boundary of the submicromolar zone, indicating effective oxidation at $\mathrm{O}_{2}$ concentrations of less than $200 \mathrm{nmol} \mathrm{O}_{2} \mathrm{~L}^{-1} \quad$ (Fig. 5c, f, i). Particulate $\mathrm{Mn}$ 


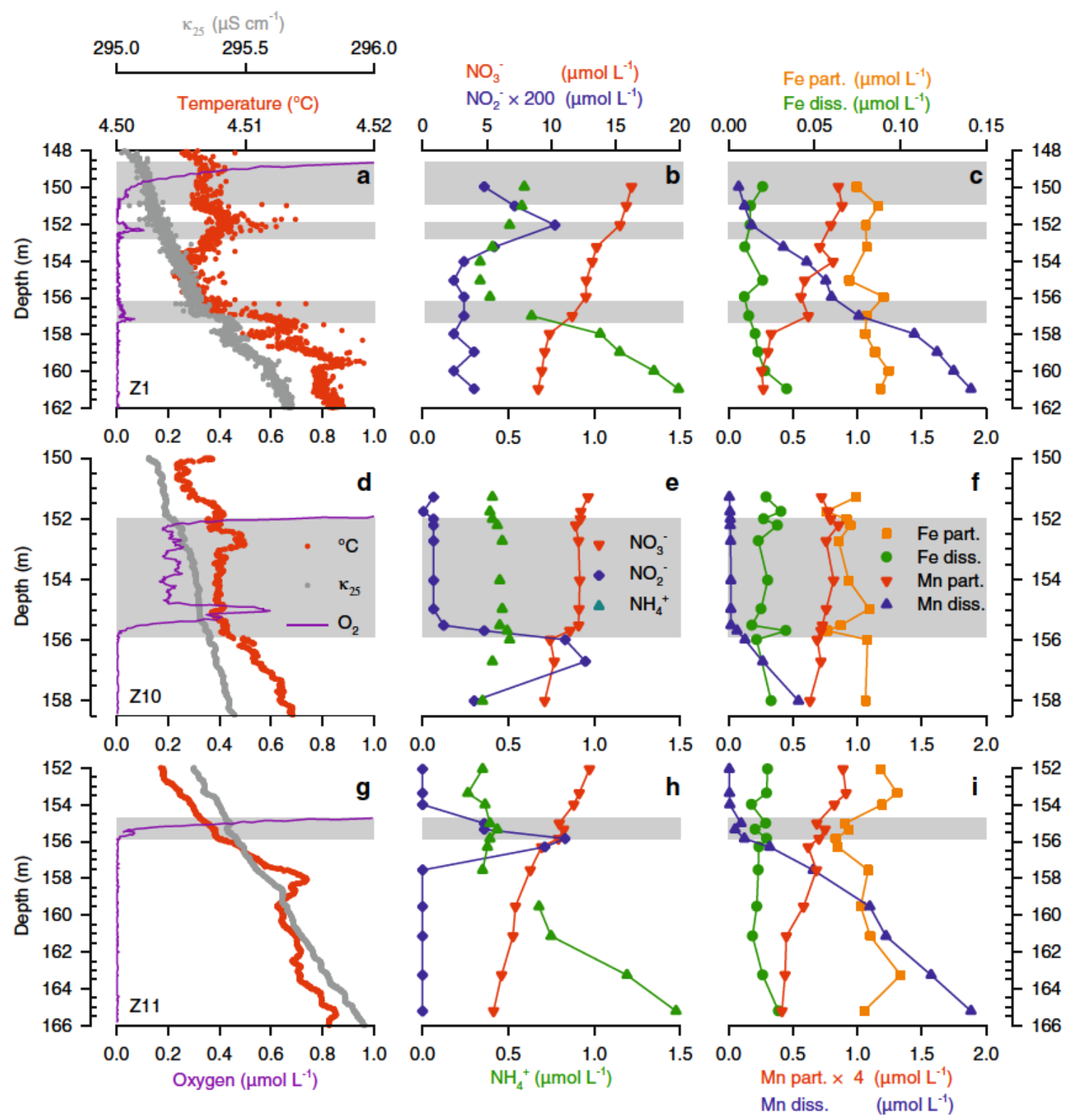

Fig. 5 Lake Zug, 25 August 2010: depth profiles of casts Z1 (top), $\mathrm{Z} 10$ (middle), and Z11 (bottom) across the oxic/anoxic interface showing the distribution of $\mathrm{O}_{2}(\mathbf{a}, \mathbf{d}, \mathbf{g}), \mathrm{N}$ species (b, e, h) and transition metals (c, $\mathbf{f}, \mathbf{i}$, particular Mn values have been multiplied by 4) together with physical gradients (a, d, g). Depths with

concentrations were elevated in the synoptic profile (Fig. 4f) in a broad zone ( $\sim 15 \mathrm{~m}$ ) around the oxic/anoxic transition at $150-160 \mathrm{~m}$ with concentrations falling below $100 \mathrm{nmol} \mathrm{L}^{-1}$ at 170 and $100 \mathrm{~m}$ depth, respectively. The high-resolution profiles (Fig. 5c, f, i) reveal the lower part of the broad peak of particulate Mn. However, within this large scale gradient local accumulation of particulate Mn could not be observed directly above the interface nor was particulate Mn significantly reduced with the onset of anoxic conditions. Particulate $\mathrm{Fe}$ increased below the oxic/ submicromolar $\mathrm{O}_{2}$ concentrations are shaded grey. Redox horizons of $\mathrm{NO}_{2}^{-}(\mathbf{b}, \mathbf{e}, \mathbf{h})$ and dissolved $\mathrm{Mn}(\mathbf{c}, \mathbf{f}, \mathbf{i})$ are closely associated to the oxic/anoxic transition, while $\mathrm{NH}_{4}{ }^{+}$concentrations fall below the detection limit (disconnected triangles) slightly below the oxic/anoxic transition (b, h)

anoxic transition with depth (Fig. 4f), whereas the generally low dissolved Fe concentrations $\left(\sim 0.025 \mu \mathrm{mol} \mathrm{L}{ }^{-1}\right)$ increased slightly only below $180 \mathrm{~m}$ but showed no clear signs of coupling to the low $\mathrm{O}_{2}$ zone.

$\mathrm{CH}_{4}$ gradients in Lake Zug were less pronounced than in Lake Rot due to lower absolute concentrations. Similar to Lake Rot, methane was oxidized within the same depth layer as dissolved $\mathrm{Mn}^{2+}$; i.e. in the submicromolar zone and at similar concentrations of around $200 \mathrm{nmolO}_{2} \mathrm{~L}^{-1}$ (Fig. 6e,f). No $\Sigma \mathrm{H}_{2} \mathrm{~S}$ was detected in the sampled anoxic water column. 


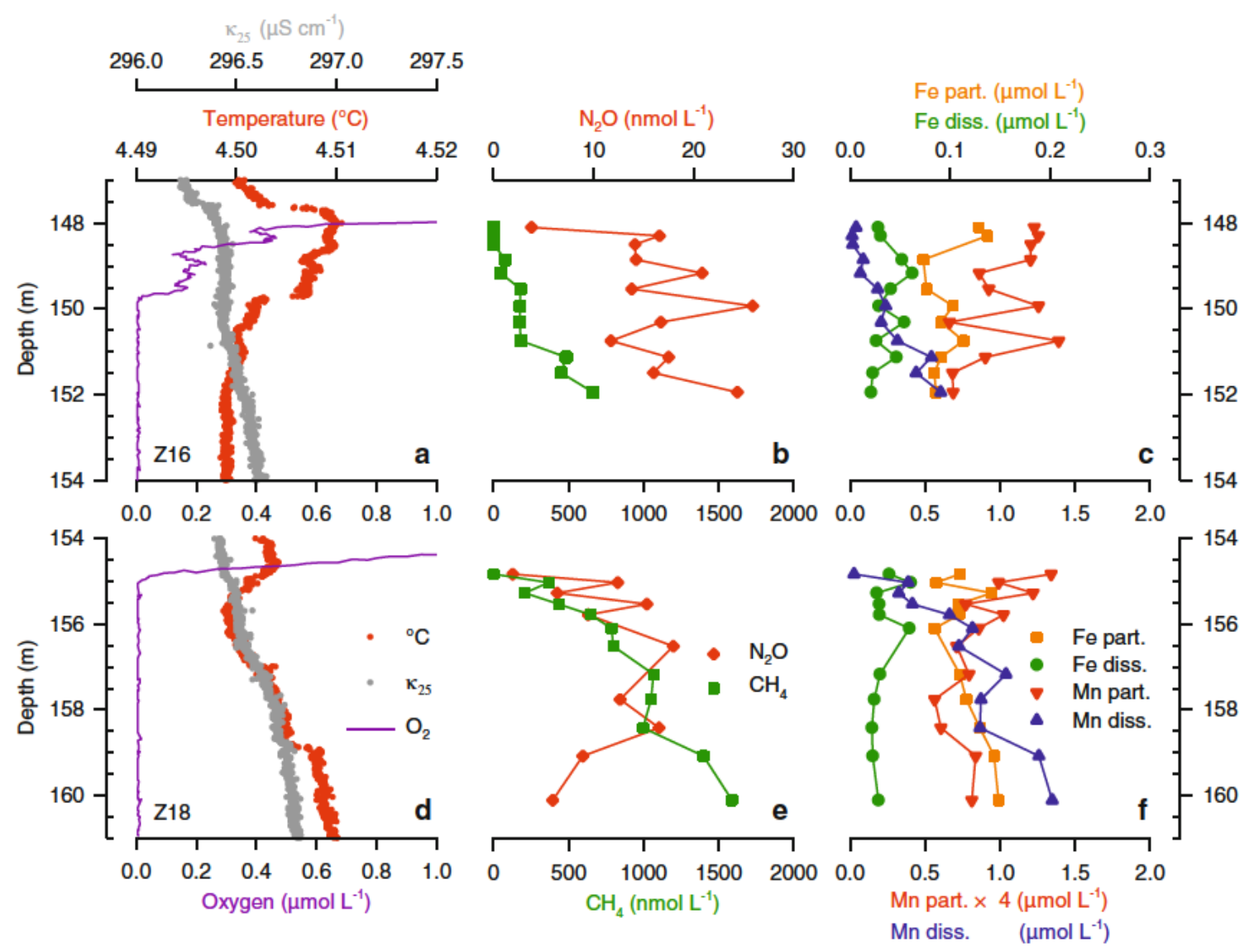

Fig. 6 Lake Zug, 25 August 2010: depth profiles of cast Z16 (top) and $\mathrm{Z} 18$ (bottom) across the oxic/anoxic interface showing the distribution of $\mathrm{O}_{2}(\mathbf{a}, \mathbf{d})$, dissolved gases $\mathrm{N}_{2} \mathrm{O}$ and $\mathrm{CH}_{4}(\mathbf{b}, \mathbf{e})$ and transition metals (c, $\mathbf{f}$, particular $\mathrm{Mn}$ values have been multiplied by

\section{Discussion}

Resolving the submicromolar zone of the oxycline

In seasonally stratified Lake Rot, a low $\mathrm{O}_{2}$ zone with an extension of about $1 \mathrm{~m}$ and distinct $\mathrm{O}_{2}$-maxima (Figs. 2c, 3a, b) was observed below the steep oxycline (Fig. 2a). The permanently stratified Lake Zug had a weaker synoptic $\mathrm{O}_{2}$ gradient where extensive zones of submicromolar $\mathrm{O}_{2}$ concentrations (up to several meters) were visible above the oxic/anoxic interface (Figs. 5a, d, g, 6a, b). The submicromolar zones could not have been resolved with traditional CTD-profiles using electrochemical or optical macro sensors. The existence of extended submicromolar layers imply a significant downward shift of the oxic/anoxic interface compared to estimates deduced from traditional CTD-profiles (Kirf et al. 2013). Without resolving submicromolar concentrations, the linear extrapolation of the $\mathrm{O}_{2}^{-}$ gradient from above 1 to $2 \mu \mathrm{mol} \mathrm{O}_{2} \mathrm{~L}^{-1}$ (the lower detection limit of many sensors) to zero $\mathrm{O}_{2}$ severely underestimates the true extension of the submicromolar
4) together with physical gradients (a,d). Depths with submicromolar $\mathrm{O}_{2}$ concentrations are shaded grey. Upward transported $\mathrm{CH}_{4}$ (b, e) and diss. $\mathrm{Mn}\left(\mathbf{c}\right.$, f) are oxidized at submicromolar $\mathrm{O}_{2}$ concentrations

zone by up to several meters (online resource 2) and lowers the estimated depth of the oxic/anoxic interface. These observations are relevant for the interpretation of suboxic zones that are defined by the absence of both $\mathrm{O}_{2}$ and $\mathrm{H}_{2} \mathrm{~S}$. If revisited with sensitive profiling equipment, such zones will probably turn out to be much thinner or even non-existing and processes like the oxidation of methane might actually occur at submicromolar $\mathrm{O}_{2}$ concentrations rather than by anaerobic pathways (Canfield and Thamdrup 2009; Bethke et al. 2011; Lehner et al. 2014).

Contributions to the submicromolar $\mathrm{O}_{2}$ zone

In Lake Zug, profiles were taken in the interior of the deep hypolimnion. Here, turbulence is extremely weak as the energy transfer from large-scale seiching to turbulent mixing occurs in the bottom boundary layer (Goudsmit et al. 1997; Wüest and Lorke 2003). The observed inhomogeneous $\mathrm{O}_{2}$ distribution, characterized by local maxima and minima in the submicromolar zone, is most likely the 
result of lateral transport of water masses with differing source oxygen concentration. Lateral transport is typically 4-5 orders of magnitude more effective than vertical mixing in deep lakes (Peeters et al. 1996). Intermittent reaction, mixing and transport processes can mix up differing water masses in the bottom boundary layer (Lorke et al. 2003; Brand et al. 2008; Müller et al. 2012) and influence the biogeochemical profiles in the interior of a lake by promoting lateral injection of oxygen as known, e.g., from the Black Sea (Konovalov et al. 2003). Lateral transport of water masses with different origin was also indicated by similar variations of temperature and $\mathrm{O}_{2}$ concentration in some of the profiles (Figs. 5a, 6a).

Variable kinetics of $\mathrm{O}_{2}$ consuming processes such as microbial respiration, the oxidation of settling organic particles (Wright et al. 2012) and of upward transported reduced chemicals might further shape the submicromolar zone (Thamdrup et al. 2012). As $\mathrm{O}_{2}$ concentrations decrease with depth, the rates of the various $\mathrm{O}_{2}$ consuming processes should be increasingly affected according to their different apparent half saturation constants (Stolper et al. 2010; Wright et al. 2012). Consequently, the bulk consumption rate should decrease, which in turn should result in the decrease of $\mathrm{O}_{2}$ flux and extend the transition zone between the oxic and anoxic water masses: such an extended submicromolar zone should be characterized by a continuous decrease of the $\mathrm{O}_{2}$ gradient (Fig. 5a, Lake Zug).

Finally, some profiles suggest rather transient $\mathrm{O}_{2}$ conditions where $\mathrm{O}_{2}$ intrusions or the oxic/anoxic interface did not yet inflict significant redox-changes. For example, the $\mathrm{Mn}_{2}{ }^{+}$gradient crosses small oxic pockets in cast Z1 (Fig. 5 a, c), while in cast Z16 (Fig. 6b, c), the $\mathrm{CH}_{4}$ and $\mathrm{Mn}_{2}{ }^{+}$ gradient both extend in parallel well across the oxic/anoxic interface. Studies conducted in various aquatic environments with low oxic to anoxic conditions showed that intermittent (lateral) $\mathrm{O}_{2}$-intrusions can contribute significantly to overall redox-budgets (Zopfi et al. 2001; Konovalov et al. 2003; Schippers et al. 2005) and thus might further sustain aerobic redox-pathways in otherwise anoxic water bodies (Lam et al. 2007; Thamdrup et al. 2012).

In stratified Lake Rot, Secchi-depths of 2.2 and $2.6 \mathrm{~m}$ recorded on 16 September 2010 and 9 September 2011 indicate a euphotic depth of 7.4 and $8.1 \mathrm{~m}$, respectively (Tilzer 1988). Sunny weather during the field campaign suggest that the increase of $\mathrm{O}_{2}$ measured over the day in the epilimnion, the oxycline and the low $\mathrm{O}_{2}$ zone (Fig. 2a, c) are caused by oxygenic photosynthesis. Patchiness in algal and microbial activity, e.g. originating from intermittent lateral intrusions of water parcels containing microorganisms and $\mathrm{O}_{2}$ from the bottom boundary layer, could modulate the balance of $\mathrm{O}_{2}$ production and respiration below the oxycline, eventually explaining the observed layering of $\mathrm{O}_{2}$ peaks at specific depths and their stability throughout the day (Fig. 2c). Highly dynamic lateral currents at a stratified pelagic oxycline, despite the lack of turbulent vertical mixing, could be demonstrated recently by Kreling et al. (2014) in a study investigating the vertical $\mathrm{O}_{2}$ transport across oxyclines and the related fine scale transport processes using a pelagic installation of the eddy correlation technique (Berg et al. 2003). The zone void of detectable $\mathrm{O}_{2}$ and $\mathrm{H}_{2} \mathrm{~S}$ found directly below the oxic/ anoxic interface (Fig. 3e) might be caused by $\mathrm{H}_{2} \mathrm{~S}$-consuming photosynthetic sulphur bacteria that are characteristic for Lake Rot (Kohler et al. 1984).

The $\mathrm{O}_{2}$ accumulation below Lake Rots oxycline over the day $\left(\sim 0.7 \mathrm{mmol} \mathrm{m}^{-2} \mathrm{~h}^{-1}\right.$ estimated from a $4 \mu \mathrm{mol} \mathrm{L}{ }^{-1}$ difference in a $1.5 \mathrm{~m}$ thick layer over $8 \mathrm{~h}$, Fig. 2c) is comparable to the flux of $\mathrm{O}_{2}$ along the oxycline $\left(\sim 0.7 \mathrm{mmol} \mathrm{m}^{-2} \mathrm{~h}^{-1}\right.$ for a gradient of $200 \mathrm{mmol} \mathrm{m}^{-4}$ and assuming a diffusivity of $10^{-6} \mathrm{~m}^{2} \mathrm{~s}^{-1}$ (Schubert et al. 2010)). This additional oxidation-potential below the oxycline should therefore be included in redox-balances on the system-level. Moreover, the calculated $\mathrm{O}_{2}$ accumulation within the low $\mathrm{O}_{2}$ zone represents only the net production, whereas the gross $\mathrm{O}_{2}$-turnover could be substantially higher due to the co-occurrence of $\mathrm{O}_{2}$ production and consumption.

\section{Redox gradients at the low $\mathrm{O}_{2}$ boundary}

Specific hotspots of redox reactions were related closely to the cast-specific depth of the oxic/anoxic interface (Figs. 3, $5,6)$. In both lakes, linear gradients terminating close to the oxic/anoxic interface $\left(\mathrm{CH}_{4}\right.$, dissolved $\mathrm{Mn}^{2+}$, Figs. 3, 5, 6) and distinct peaks $\left(\mathrm{NO}_{2}^{-}, \mathrm{N}_{2} \mathrm{O}\right.$, particulate $\mathrm{Mn}$ in Lake Rot (Fig. 3), $\mathrm{NO}_{2}^{-}$in Lake Zug (Fig. 5)) imply that these specific redox horizons have existed over time scales relevant for microbial processes. The position of the chemical gradients and concentration peaks with regards to the $\mathrm{O}_{2}$ profile indicate that the hitherto unnoticed nanomolar $\mathrm{O}_{2}$ concentrations do indeed significantly influence redoxcycling. In accordance with recent marine studies (Revsbech et al. 2009; Kalvelage et al. 2011; Thamdrup et al. 2012), this field study confirms that the arbitrarily chosen traditional threshold for the oxic/anoxic transition of $1 \mu \mathrm{mol} \mathrm{O} \mathrm{O}_{2} \mathrm{~L}^{-1}$ is by at least one order of magnitude too high to adequately detect and classify $\mathrm{O}_{2}$ dependent redoxinteractions in natural systems.

In both lakes, the high-resolution profiles clearly show that $\mathrm{O}_{2}$ availability in the submicromolar range is a key factor to explain the observed locations of $\mathrm{Mn}$ and $\mathrm{CH}_{4}$ oxidation. $\mathrm{Mn}^{2+}$ and $\mathrm{CH}_{4}$ are consistently oxidized within the same depth-horizon, which is clearly associated to the depth of the oxic/anoxic interface (Figs. 3, 5, 6). Since Mn reacts quickly to changing redox-conditions if microbially 
Table 1 Electron balances of Lake Rot and Lake Zug across the oxic/anoxic transition

\begin{tabular}{|c|c|c|c|c|}
\hline Analyte & $\begin{array}{l}\text { Lake Rot gradient } \\
\left(\mathrm{mmol} \mathrm{m}^{-4}\right)\end{array}$ & $\begin{array}{l}\text { Electron equivalent } \\
\text { gradient }\left(\mathrm{mmol} \mathrm{m}^{-4}\right)\end{array}$ & $\begin{array}{l}\text { Lake Zug gradient } \\
\left(\mathrm{mmol} \mathrm{m}^{-4}\right)\end{array}$ & $\begin{array}{l}\text { Electron equivalent gradient } \\
\left.(\mathrm{mmol} \mathrm{m})^{-4}\right)\end{array}$ \\
\hline $\mathrm{O}_{2}$ & 212.0 & 848.0 & 2.2 & 8.8 \\
\hline $\mathrm{NO}_{3}$ & 37.2 & 186.0 & 0.21 & a \\
\hline $\mathrm{NH}_{4}^{+}$ & 14.2 & a & 0.14 & 1.12 \\
\hline Dissolved $\mathrm{Mn}^{2+}$ & 3.3 & 6.6 & 0.13 & 0.25 \\
\hline Dissolved Fe & 0.3 & 0.3 & & \\
\hline $\mathrm{CH}_{4}$ & 46.0 & 368.0 & 0.61 & 4.88 \\
\hline $\mathrm{H}_{2} \mathrm{~S}$ & 19.5 & a & & \\
\hline Sum reacting oxidants & & 1,034 & & 8.8 \\
\hline Sum reacting reductants & & 375 & & 6.3 \\
\hline Total & & 659 & & 2.5 \\
\hline
\end{tabular}

${ }^{a}$ No prominent reaction in low oxygen zone or oxidation by photosynthesis

mediated (Tebo et al. 2004; Jones et al. 2011), the termination of the linear dissolved $\mathrm{Mn}^{2+}$-gradients closely above the oxic/anoxic interface in both lakes corroborates an $\mathrm{O}_{2}$ dependency of in situ Mn-oxidation (Schippers et al. 2005; Clement et al. 2009).

In contrast to the turnover of $\mathrm{Mn}^{2+}$ and $\mathrm{CH}_{4}$ near the oxic/anoxic interface, the sites of nitrogen cycling were positioned close to the oxycline in Lake Rot (Fig. 2b, e). The linear $\mathrm{NH}_{4}{ }^{+}$concentration gradient (Fig. 3b) suggests that the net flux of $\mathrm{NH}_{4}{ }^{+}$from lower depths to the surface is unaffected by the first appearance of $\mathrm{O}_{2}$, whereas further above at $\sim 5 \mathrm{~m}$ depth, increased consumption either by algae uptake or by nitrification is indicated by the termination of the $\mathrm{NH}_{4}{ }^{+}$gradient (Figs. 3b, 4a). Schubert et al. (2010) documented similar observations, thus $\mathrm{NH}_{4}{ }^{+}$-reactivity appears low at the given environmental conditions below the oxycline. Downward net transport of nitrate decreased directly at the lower end of the steep oxycline, suggesting nitrate reduction which is also supported by the pronounced peaks of $\mathrm{NO}_{2}^{-}$at $6.25 \mathrm{~m}$ and $\mathrm{N}_{2} \mathrm{O}$ slightly below (Fig. 3b, e). Intermediate oxidized $\mathrm{N}$-species thus occurred and disappeared within a narrow layer of only $50 \mathrm{~cm}\left(\mathrm{NO}_{2}{ }^{-}\right)$to $80 \mathrm{~cm}\left(\mathrm{~N}_{2} \mathrm{O}\right)$ after $\mathrm{O}_{2}$-availability severely dropped along Lake Rot steep oxycline. The observed spatial sequence of increasingly reduced $\mathrm{N}$-species follows the sequence expected from the increased sensitivity of $\mathrm{N}$-reducing enzymes towards $\mathrm{O}_{2}$ (Bonin et al. 1989) and different kinetics of the involved intermediate steps of denitrification (Wild et al. 1995).

$\mathrm{NH}_{4}{ }^{+}$-oxidation in Lake Zug was associated to the oxic/ anoxic interface (Fig. 5b, e, h). The $\mathrm{NH}_{4}{ }^{+}$gradient from below was almost linear. $\mathrm{NH}_{4}{ }^{+}$concentrations fell below the detection level 2-4 $\mathrm{m}$ below the oxic/anoxic interface, but the linearly extrapolated $\mathrm{NH}_{4}{ }^{+}$gradient reaches zero $\mathrm{NH}_{4}{ }^{+}$at the depth horizon of the oxic/anoxic interface (Fig. 5b, h). The depth where the last traces of $\mathrm{O}_{2}$ disappear, and where ammonium apparently also disappears, is associated with small nitrite-peaks (Fig. 5b, h), presumably formed as a by-product of aerobic ammonium oxidation, and with local maxima of nitrate (Fig. 5h). Aerobic nitrification was found active even at $\mathrm{O}_{2}$ concentrations below $50 \mathrm{nmol} \mathrm{L}^{-1}$ (Kalvelage et al. 2011). However, the small nitrite peak found below the submicromolar zone (Fig. 5e) corresponds to a local nitrate minimum and might indicate co-occurring nitrate reduction.

In Lake $\mathrm{Zug}, \mathrm{O}_{2}$ availability around or below the current detection limit of $\sim 10 \mathrm{nmol} \mathrm{\textrm {L } ^ { - 1 }}$ appears sufficient to initiate oxidation of $\mathrm{CH}_{4}, \mathrm{Mn}^{2+}$ and $\mathrm{NH}_{4}{ }^{+}$. As there is no physical interface associated to the oxic/anoxic interface, the vertical diffusivity can be assumed constant across this layer and can be ignored. Thus, we can construct a flux balance based on the synoptic downward gradients of $\mathrm{O}_{2}$ on one side and on the upward gradients of $\mathrm{CH}_{4}$, dissolved $\mathrm{Mn}^{2+}$ and $\mathrm{NH}_{4}{ }^{+}$on the other side. The flux balance reveals that the fluxes of $\mathrm{CH}_{4}$, dissolved $\mathrm{Mn}^{2+}$ and $\mathrm{NH}_{4}{ }^{+}$together account for $\sim 70 \%$ of the $\mathrm{O}_{2}$ flux when normalized to redox equivalents (Stumm and Morgan 1995) (Table 1). A significant part of this turnover seems to occur within the submicromolar $\mathrm{O}_{2}$ zone which extended on average over $2 \mathrm{~m}$ in Lake Zug.

\section{Conclusions}

$\mathrm{O}_{2}$ measurements with high temporal resolution and sensitivity show that $\mathrm{O}_{2}$ controls the biogeochemical cycling of $\mathrm{N}, \mathrm{Mn}$ and $\mathrm{CH}_{4}$ in dynamic layers with submicromolar $\mathrm{O}_{2}$ concentrations. Specific hotspots of redox-reactions were found to be closely related to the cast-specific depth of the oxic/anoxic interface. In Lake $\mathrm{Zug}, \mathrm{O}_{2}$ availability around or below the in situ detection limit of $\sim 10 \mathrm{nmol}$ 
$\mathrm{O}_{2} \mathrm{~L}^{-1}$ appears sufficient to initiate oxidation of $\mathrm{CH}_{4}$, $\mathrm{Mn}^{2+}$ and $\mathrm{NH}_{4}{ }^{+}$at a water depth of $\sim 160 \mathrm{~m}$. Below the steep oxycline of Lake Rot, deep oxygenic photosynthesis could well be responsible for the observed low-level oxygen concentrations which can drive a significant part of the chemotrophic oxidation processes at a water depth of 6$7.5 \mathrm{~m}$. The historically accepted $1 \mu \mathrm{mol} \mathrm{O} \mathrm{O}_{2} \mathrm{~L}^{-1}$ detection limit as indicator for anoxic conditions is definitely too high to adequately detect and classify $\mathrm{O}_{2}$-dependent redoxreactions and to analyze the biogeochemical structure of oxic/anoxic boundaries in natural systems. The new evidence for an extended, heterogeneous and dynamic lowoxygen interface invites more investigations with sensitive profiling devices at proper scales in order to further elucidate microbial pathways and their significance for element cycling across the oxic/anoxic transition. Parts of previously described "suboxic" zones with missing $\mathrm{O}_{2}$ and $\mathrm{H}_{2} \mathrm{~S}$ might in fact belong to the realm of oxic processes if characterized with submicromolar sensitivity.

Acknowledgments We thank Eric Epping and Volker Meyer for valuable ideas supporting the measuring setup. We thank Dörte Carstens, Manuel Kunz, Gianna Battaglia, Christian Dinkel, Gijs Nobbe, Enoma Omoregie, Ruth Stierli and Alois Zwyssig for help in the laboratory and in the field and the cantonal agency Lucerne Environment and Energy for provided Secchi data. Johny Wüest and Britta Bohnenbuck are acknowledged for comments on the text. The project was funded by Eawag and benefitted from the interaction with team members of the EU project "Hypox" (EC grant \# 22613).

\section{References}

Benson BB, Krause D (1984) The concentration and isotopic fractionation of oxygen dissolved in fresh water and seawater in equilibrium with the atmosphere. Limnol Oceanogr 29(3):620 632. doi:10.4319/lo.1984.29.3.0620

Berg P, Røy H, Janssen F, Meyer V, Jørgensen BB, Huettel M, de Beer D (2003) Oxygen uptake by aquatic sediments measured with a novel non invasive eddy correlation technique. Mar Ecol Prog Ser 261:75 83. doi:10.3354/Meps261075

Berner RA (1981) A new geochemical classification of sedimentary environments. J Sediment Petrol 51(2):359 365. doi:10.1306/ 212F7C7F 2B24 11D7 8648000102C1865D

Bethke CM, Sanford RA, Kirk MF, Jin QS, Flynn TM (2011) The thermodynamic ladder in geomicrobiology. Am J Sci 311(3):183 210. doi:10.2475/03.2011.01

Bonin P, Gilewicz M, Bertrand JC (1989) Effects of oxygen on each step of denitrification on Pseudomonas nautica. Can J Microbiol 35(11): 10611064

Brand A, McGinnis DF, Wehrli B, Wüest A (2008) Intermittent oxygen flux from the interior into the bottom boundary of lakes as observed by eddy correlation. Limnol Oceanogr 53(5):1997 2006. doi:10.4319/1o.2008.53.5.1997

Canfield DE, Thamdrup B (2009) Towards a consistent classification scheme for geochemical environments, or, why we wish the term 'suboxic' would go away. Geobiology 7(4):385 392. doi:10. 1111/j.1472 4669.2009.00214.x
Clement BG, Luther GW III, Tebo BM (2009) Rapid, oxygen dependent microbial $\mathrm{Mn}(\mathrm{II})$ oxidation kinetics at sub micromo lar oxygen concentrations in the Black Sea suboxic zone. Geochim Cosmochim Ac 73(7):1878 1889. doi:10.1016/j.gca. 2008.12.023

Cline JD (1969) Spectrophotometric determination of hydrogen sulfide in natural waters. Limnol Oceanogr 14:454 458

DEV (2004) Deutsche einheitsverfahren zur wasser abwasser und schlammuntersuchung. Wiley, Weinheim

Garcia HE, Gordon LI (1992) Oxygen solubility in seawater better fitting equations. Limnol Oceanogr 37(6):1307 1312. doi:10. 4319/lo.1992.37.6.1307

Goudsmit GH, Peeters F, Gloor M, Wüest A (1997) Boundary versus internal diapycnal mixing in stratified natural waters. J Geophys Res Oceans 102(C13):27903 27914. doi:10.1029/97JC01861

Gray JS, Wu RSS, Or YY (2002) Effects of hypoxia and organic enrichment on the coastal marine environment. Mar Ecol Prog Ser 238:249 279

Jones C, Crowe SA, Sturm A, Leslie KL, MacLean LCW, Katsev S, Henny C, Fowle DA, Canfield DE (2011) Biogeochemistry of manganese in ferruginous Lake Matano. Indonesia Biogeo sciences 8(10):2977 2991. doi:10.5194/bg 829772011

Kalvelage T, Jensen MM, Contreras S, Revsbech NP, Lam P, Gunter M, LaRoche J, Lavik G, Kuypers MMM (2011) Oxygen sensitivity of anammox and coupled $\mathrm{N}$ cycle processes in oxygen minimum zones. Plos One 6(12):e29299. doi:10.1371/ journal.pone.0029299

Keeling RF, Kortzinger A, Gruber N (2010) Ocean deoxygenation in a warming world. Annu Rev Mar Sci 2:199 229. doi:10.1146/ annurev.marine.010908.163855

Kirf MK, Dinkel C, Schubert C, Wehrli B (2013) Submicromolar oxygen profiles at the oxic anoxic boundary of temperate lakes. Aquat Geochem 1 19. doi:10.1007/s10498 01392067

Kohler HP, Ahring B, Albella C (1984) Bacteriological studies on the sulfur cycle in the anaerobic part of the hypolimnion and in the surface sediments of Rotsee in Switzerland. FEMS Microbiol Lett 21(3):279 286. doi:10.1111/j.1574 6968.1984.tb00322.x

Konovalov SK, Luther GW, Friederich GE, Nuzzio DB, Tebo BM, Murray JW, Oguz T, Glazer B, Trouwborst RE, Clement B, Murray KJ, Romanov AS (2003) Lateral injection of oxygen with the Bosporus plume fingers of oxidizing potential in the Black Sea. Limnol Oceanogr 48(6):2369 2376

Kreling J, Bravidor J, McGinnis DF, Koschorreck M, Lorke A (2014) Physical controls of oxygen fluxes at pelagic and benthic oxyclines in a lake. Limnol Oceanogr 59(5):1637 1650. doi:10. 4319/1o.2014.59.5.1637

Lam P, Kuypers MMM (2011) Microbial nitrogen cycling processes in oxygen minimum zones. Annu Rev Mar Sci 3:317 345. doi:10.1146/annurev marine 120709142814

Lam P, Jensen MM, Lavik G, McGinnis DF, Müller B, Schubert CJ, Amann R, Thamdrup B, Kuypers MMM (2007) Linking crenarchaeal and bacterial nitrification to anammox in the Black Sea. P Natl Acad Sci USA 104(17):7104 7109

Lashof DA, Ahuja DR (1990) Relative contributions of greenhouse gas emissions to global warming. Nature 344(6266):529 531. doi: $10.1038 / 344529 \mathrm{a} 0$

Lehner P, Staudinger C, Borisov SM, Klimant I (2014) Ultra sensitive optical oxygen sensors for characterization of nearly anoxic systems. Nat Commun 5. doi:10.1038/ncomms5460

Lippitsch ME, Pusterhofer J, Leiner MJP, Wolfbeis OS (1988) Fibre optic oxygen sensor with the fluorescence decay time as the information carrier. Anal Chim Acta 205(1 2):1 6. doi:10.1016/ S0003 2670(00)82310 7

Lorke A, Müller B, Maerki M, Wüest A (2003) Breathing sediments: the control of diffusive transport across the sediment water 
interface by periodic boundary layer turbulence. Limnol Ocea nogr 48(6):2077 2085. doi:10.4319/lo.2003.48.6.2077

Maerki M, Müller B, Dinkel C, Wehrli B (2009) Mineralization pathways in lake sediments with different oxygen and organic carbon supply. Limnol Oceanogr 54(2):428 438. doi:10.4319/lo. 2009.54.2.0428

Mulder A, van de Graaf AA, Robertson LA, Kuenen JG (1995) Anaerobic ammonium oxidation discovered in a denitrifying fluidized bed reactor. FEMS Microbiol Ecol 16(3):177 184. doi:10.1111/j.1574 6941.1995.tb00281.x

Müller B, Bryant LD, Matzinger A, Wüest A (2012) Hypolimnetic oxygen depletion in eutrophic lakes. Environ Sci Technol 46(18):9964 9971. doi:10.1021/es301422r

Peeters F, Wüest A, Piepke G, Imboden DM (1996) Horizontal mixing in lakes. J Geophys Res Oceans 101(C8):18361 18375. doi:10.1029/96JC01145

Revsbech NP, Larsen LH, Gundersen J, Dalsgaard T, Ulloa O, Thamdrup B (2009) Determination of ultra low oxygen concen trations in oxygen minimum zones by the STOX sensor. Limnol Oceanogr Methods 7:371 381. doi:10.4319/lom.2009.7.371

Schippers A, Neretin LN, Lavik G, Leipe T, Pollehne F (2005) Manganese(II) oxidation driven by lateral oxygen intrusions in the western Black Sea. Geochim Cosmochim Ac 69(9):2241 2252. doi:10.1016/j.gca.2004.10.016

Schubert CJ, Lucas FS, Durisch Kaiser E, Stierli R, Diem T, Scheidegger O, Vazquez F, Müller B (2010) Oxidation and emission of methane in a monomictic lake (Rotsee, Switzerland). Aquat Sci 72(4):455 466. doi:10.1007/s00027 01001485

Seitzinger SP, Nixon SW, Pilson MEQ (1984) Denitrification and nitrous oxide production in a coastal marine ecosystem. Limnol Oceanogr 29(1):73 83

Stolper DA, Revsbech NP, Canfield DE (2010) Aerobic growth at nanomolar oxygen concentrations. P Natl Acad Sci USA 107(44):18755 18760. doi:10.1073/pnas.1013435107

Stumm W, Morgan J (1995) Aquatic chemistry: Chemical equilibria and rates in natural waters, 3rd edn. John Wiley \& Sons, New York, USA
Tebo BM, Bargar JR, Clement BG, Dick GJ, Murray KJ, Parker D, Verity R, Webb SM (2004) Biogenic manganese oxides: properties and mechanisms of formation. Annu Rev Earth Pl Sc 32:287 328. doi:10.1146/annurev.earth.32.101802.120213

Thamdrup B, Dalsgaard T, Revsbech NP (2012) Widespread func tional anoxia in the oxygen minimum zone of the Eastern South Pacific. Deep Sea Res Part I 65:36 45. doi:10.1016/j.dsr.2012. 03.001

Tilzer MM (1988) Secchi disk chlorophyll relationships in a lake with highly variable phytoplankton biomass. Hydrobiologia 162(2): 163171

Verbruggen F, Heiri O, Reichart GJ, Lotter AF (2010) Chironomid $\delta^{18} \mathrm{O}$ as a proxy for past lake water $\delta^{18} \mathrm{O}$ : a lateglacial record from Rotsee (Switzerland). Quaternary Sci Rev 29(17 18):2271 2279. doi:10.1016/j.quascirev.2010.05.030

Weiss RF, Price BA (1980) Nitrous oxide solubility in water and seawater. Mar Chem 8(4):347 359

Wiesenburg DA, Guinasso NL (1979) Equilibrium solubilities of methane, carbon monoxide, and hydrogen in water and sea water. J Chem Eng Data 24(4):356 360

Wild D, von Schulthess R, Gujer W (1995) Structured modeling of denitrification intermediates. Water Sci Technol 31(2):45 54. doi:10.1016/0273 1223(95)00179 Q

Winkler LW (1888) Die Bestimmung des im Wasser gelösten Sauerstoffes. Ber Dtsch Chem Ges 21(2):2843 2854. doi:10. 1002/cber.188802102122

Wright JJ, Konwar KM, Hallam SJ (2012) Microbial ecology of expanding oxygen minimum zones. Nat Rev Microbiol 10(6):381 394. doi: $10.1038 /$ Nrmicro 2778

Wüest A, Lorke A (2003) Small scale hydrodynamics in lakes. Annu Rev Fluid Mech 35:373 412. doi:10.1146/annurev.fluid.35. 101101.161220

Zopfi J, Ferdelman TG, Jørgensen BB, Teske A, Thamdrup B (2001) Influence of water column dynamics on sulfide oxidation and other major biogeochemical processes in the chemocline of Mariager Fjord (Denmark). Mar Chem 74(1):29 51 